Економічні науки: збірник наукових прачь Луиького національного технічного університету. Серія "Регіональна економіка". Випуск 17 (67). Редкол.: відп. ред. к.е.н., професор І.В. Кривов’язюк. Луцьк: ІВВ Луцького НТУ, 2020. 348 с.

УДК 338.431(477):349.42

Газуда Леся Михайлівна,

д.е.н., професор, кафедра економіки і підприємництва

Пінцак Святослав Мирославович, аспірант кафедри економіки і підприємництва, Сойма Світлана Юріївна,

к.е.н., доцент, кафедра бізнес-адміністрування, маркетингу та менеджменту

ДВНЗ «Ужгородський національний університет»

\title{
ДО ПИТАННЯ СУТНІСНОГО І ПРАВОВОГО ВИЗНАЧЕННЯ АГРАРНОГО ПІДПРИЕМНИЦТВА
}

У статті висвітлено наукові підходи до тлумачення поняття аграрного підприємництва як специфічного виду економічної діяльності в умовах ринкового господарювання, розвиток якого дає значний поштовх економічному зростанню країни та її регіонів. Окреслено економічні і правові відносини у сфері ведення сільського господарства. Виокремлено підходи до обгрунтування класифікацій суб' єктів аграрних правовідносин, заснованих на різних формах власності, за сферою і предметом діяльності.

Ключові слова: аграрне підприємництво, аграрне право, аграрний бізнес, фермерське господарювання, сільське господарство.

\section{Hazuda L., Pintsak S., Soyma S.}

\section{ON THE ISSUE OF THE ESSENTIAL AND LEGAL DEFINITION OF AGRICULTURAL ENTREPRENEURSHIP}

The article highlights the scientific approaches to the interpretation of the concept of agricultural entrepreneurship as a specific type of economic activity in a market economy, the development of which gives a significant impetus to economic growth of the country and its regions. Economic and legal relations in the field of agriculture have been outlined. Approaches to the substantiation of classifications of subjects of agrarian legal relations based on various forms of ownership, by sphere and subject of activity have been singled out as well. Approaches to providing farming as one of the forms of entrepreneurship of citizens for the purpose of production, processing and sale of marketable agricultural products are considered in the paper. Through the prism of multifunctionality and interdependence of the combination of economic interests and relationships between agricultural producers, industry and the trade sector where goods are sold, emphasis is placed on the importance of the functioning of business entities in the field of agribusiness. It has 
Економічні науки: збірник наукових прачь Луиького національного технічного університету. Серія "Регіональна економіка". Випуск 17 (67). Редкол.: відп. ред. к.е.н., професор І.В. Кривов’язюк. Луцьк: ІВВ Луцького НТУ, 2020. 348 с.

been proved that the efficiency of management in the agricultural sector, being associated primarily with land relations, regardless of ownership, is influenced primarily by a number of factors, the main of which are natural and climatic, investment and innovation. The human factor, which combines both the accumulated potential and human capital with its creativity and literacy, the timeliness of management decisions, addressing the current economic problems in the field of agricultural entrepreneurship. At the same time, the human factor is important because it combines both the accumulated potential and human capital with its creativity and literacy, and timeliness of management decisions in order to solve current economic problems in the field of agricultural entrepreneurship. Based on the generalization of scientific approaches to the essential understanding of agricultural entrepreneurship the author's vision of its content as a specific type of economic activity has been outlined. It involves significant resources, including natural and climatic, investment and innovation, organizational and financial, intellectual, etc., which together in the process of agricultural production enables the entrepreneur, despite the risk and high responsibility, to make a profit on a legal basis. It is noted that agrarian law should relate to those legal relations in the process of agrarian management, which will allow to maintain a balance between profit maximization and rational, careful treatment of natural resources used in the production of agricultural products.

Key words: agrarian entrepreneurship, agrarian law, agrarian business, farming, agriculture.

\section{Газуда Л.М., Пинцак С.М., Сойма С.Ю. К ВОПРОСУ СУЩНОСТНОГО И ПРАВОВОГО ОПРЕДЕЛЕНИЯ АГРАРНОГО ПРЕДПРИНИМАТЕЛЬСТВА}

В статье освещены научные подходы к толкованию понятия аграрного предпринимательства как специфического вида экономической деятельности в условиях рыночного хозяйствования, развитие которого дает значительный толчок экономическому росту страны и ее регионов. Определены экономические и правовые отношения в сфере ведения сельского хозяйства. Выделены подходы к обоснованию классификации субъектов аграрных правоотношений, основанных на различных формах собственности, по сфере и предмета деятельности.

Ключевые слова: аграрное предпринимательство, аграрное право, аграрный бизнес, фермерское хозяйство, сельское хозяйство.

Постановка проблеми. Підприємницька діяльність передбачає певну суб'єктність у процесі здійснення, що зумовлюється зівставленням і оцінюванням підприємницьких можливостей у різних сферах і видах економічної діяльності під 
Економічні науки: збірник наукових прачь Луиького національного технічного університету. Серія "Регіональна економіка". Випуск 17 (67). Редкол.: відп. ред. к.е.н., професор І.В. Кривов'язюк. Луиьк: ІВВ Луцького НТУ, 2020. 348 с.

впливом зовнішнього і внутрішнього середовища, 3 урахуванням їх правової, організаційної та економіко-соціальної специфіки. Відмінними від інших галузей $\epsilon$ особливості функціонування суб'єктів підприємництва у сфері аграрного господарювання, 3 наявними переробними й обслуговуючими підприємствами агропромислового комплексу, де формується продовольче забезпечення країни та іiі регіонів, відбувається розвиток територій сільської місцевості в цілому.

Нині аграрне виробництво $є$ однією 3 провідних експортно-орієнтованих галузей, що сприяє розвитку економіки країни. Водночас у межах розвитку сільських територіальних систем набуває активізації аграрне підприємництво.

Аналіз останніх досліджень і публікацій. Наукові підходи до сутнісного аналізу й розуміння аграрного підприємництва в цілому i його складників зокрема досліджувалися вітчизняними науковцями, такими, як В. Іванюта, В. Курило, М. Малік, Л. Риковська, І. Сурай, I. Цимбалюк О. Шпикуляк та ін. Особливості формування й організації агробізнесу як виду підприємницької діяльності, пов'язаної зі сферою виробництва засобів виробництва для ведення сільського господарства й виробництва 3 переробки та реалізації сільськогосподарської продукції, формування економічних відносин у процесі започаткування власної справи розглядалися у працях вітчизняних та зарубіжних науковців I. Абрамовича, Г. Андрусенка, Р. Голдберга, Дж. Девіса, В. Мартьянова, В. Савченка, М. Садикова, В. Семенова, I. Сіваченка, В. Федоряка та ін. Законодавчо-правові аграрні відносини й регулювання зазначеного процесу з обгрунтуванням поняття аграрного права окреслювалися у науковому доробку В. Гайворонського, В. Жушмана та ін.

Однак, попри значні наукові пошуки у сфері аграрного підприємництва й розкриття наукових підходів до його тлумачення, поглибленого дослідження потребують окремі аспекти взаємозумовленості економічних і правових основ його функціонування. 
Економічні науки: збірник наукових прачь Луиького національного технічного університету. Серія "Регіональна економіка". Випуск 17 (67). Редкол.: відп. ред. к.е.н., професор І.В. Кривов'язюк. Луиьк: ІВВ Луцького НТУ, 2020. 348 с.

Метою статті $\epsilon$ узагальнення науково-теоретичних підходів до розуміння сутності понять, пов'язаних з аграрним підприємництвом і забезпечення правовідносин у цій сфері.

Виклад основного матеріалу дослідження. Підприємництво як специфічний вид економічної діяльності в умовах ринкового господарювання зумовлює значну активізацію економічного зростання. Це ризикова діяльність, оскільки підприємець бере всю повноту відповідальності щодо реалізації окреслених цілей і завдань, отримання прибутку. При цьому він повинен володіти економічними знаннями, особливим мисленням, стилем поведінки, адаптаційними навиками, які в період трансформаційних змін дають змогу швидко вирішувати проблемні питання процесу господарювання.

Сільськогосподарська діяльність, як зазначають науковці [2, с. 14], має певну специфіку, тобто пов'язаність із використанням природних властивостей земель сільськогосподарського призначення. 3 огляду на відмічене, аграрне право, поряд із земельним, регулює відносини, що виникають у цьому аспекті. В межах окреслення норм аграрного права України врегульовуються питання розвитку соціальної сфери села, створення належного рівня життя селян, а також відносини у сфері переробки сільськогосподарської сировини, реалізації відповідної продукції. При цьому суб'єкти аграрного права визначаються як виробники сільськогосподарської продукції, передусім на основі задіяння земельних ресурсів сільськогосподарського призначення 3 метою виробництва продукції, яка в подальшому реалізується споживачеві незалежно від проживання (у місті чи в селі). Крім цього, зазначені суб' єкти володіють відособленим майном, наділені спеціальною правоздатністю і дієздатністю (правосуб'єктністю).

Господарським кодексом врегульовуються питання стосовно права власності, де зазначено (с. 134), що „суб'єкт господарювання, який здійснює господарську діяльність на основі права власності, на свій розсуд, одноосібно або спільно 3 іншими суб'єктами володіє, користується і розпоряджається належним йому (їм) майном, у тому числі має право надати 
Економічні науки: збірник наукових прачь Луиького національного технічного університету. Серія "Регіональна економіка". Випуск 17 (67). Редкол.: відп. ред. к.е.н., професор І.В. Кривов'язюк. Луиьк: ІВВ Луцького НТУ, 2020. 348 с.

майно іншим суб'єктам для використання його на праві власності, праві господарського відання чи праві оперативного управління, або на основі інших форм правового режиму майна..." [4].

Серед суб'єктів аграрних правовідносин, заснованих на різних формах власності, за сферою і предметом діяльності виокремлюються чотири взаємопов'язані групи, зокрема засновані на [8]:

- приватній власності (фермерські господарства);

- колективній формі власності, тобто спілки селян, а також виробники корпоративного типу: акціонерні товариства, асоціації, концерни, товариства з обмеженою відповідальністю, орендні формування та ін.;

-державній формі власності і такі суб'єкти, як державні підприємства;

-змішаній формі власності, тобто на кількох формах власності в їх поєднанні. Зокрема, суб'єкти сфери сервісу можуть бути засновані на будь-якій формі власності (аграрні підприємства агротехнологічного, фінансово-кредитного, комерційного i страхового сервісу). До прикладу, сервісні підприємства 3 технологічного обслуговування i виконання ремонтних робіт можуть засновуватись на приватній, державній або змішаній формах власності.

У сфері аграрного господарювання підприємницька діяльність базується на основі врахування загальних принципів, починаючи 3 вільного вибору виду діяльності, постачальників $\mathrm{i}$ споживачів вироблюваної продукції, товарів чи надання послуг, найму працівників і закінчуючи розпоряджанням отриманим прибутком. Однак у сфері ведення сільського господарства необхідно враховувати його специфіку через безпосередній вплив природної і кліматичної складових розвитку зазначеної галузі. Такі особливості сільськогосподарського виробництва, тобто створення додаткової вартості, чітко вирізняють його 3-поміж інших виробництв, відокремлюючи за підходом, де у процесі його здійснення відбувається взаємодія між суб' єктами підприємницької діяльності. Функцію регулювання таких 
Економічні науки: збірник наукових прачь Луиького національного технічного університету. Серія "Регіональна економіка". Випуск 17 (67). Редкол.: відп. ред. к.е.н., професор І.В. Кривов'язюк. Луиьк: ІВВ Луцького НТУ, 2020. 348 с.

взаємовідносин у цьому разі виконують норми права, зокрема й аграрного. Розглядаючи такого роду зв'язки крізь призму правового поля, застосовують законодавчо-правовий підхід до визначення сутності аграрного підприємництва.

Формування соціально-економічного підходу у сфері підприємництва, поряд з економічною складовою, передбачає передусім надання послуг для задоволення потреб побутового i соціально-культурного характеру як безпосередньо власних працівників, так і працівників сфери обслуговування.

Багатогранність наукових підходів до окреслення складників і змістового наповнення поняття підприємництва в цілому та аграрного підприємництва, зокрема дає підстави стверджувати, що тлумачення цих понять має дискусійний i комплексний характер, передусім через необхідність поєднання i взаємодію багатьох елементів формування сприятливого підприємницького середовища.

Дискусійність трактування досліджуваних понять полягає в тому, що в окремих наукових обгрунтуваннях не акцентується увага на ризикованості підприємницької сфери, в інших - на систематичності чи відношенні до державної реєстрації або соціального результату. Комплексність полягає в окресленні підходів до розкриття сутності цих понять, де головними $є$ управлінські навички, необхідні для запуску та ведення прибуткового аграрного бізнесу, а відтак - „підприємницький дух", який проявляється у здатності підприємця знайти та реалізувати певну можливість, яка матиме економічний та соціальний ефект. Відмічені підходи взаємодоповнюють один одного i мають вагоме значенняу процесі формування підприємницького середовища в аграрному секторі.

У Господарському кодексі України (с. 42) чітко визначено підприємництво як самостійна, ініціативна, систематична, на власний ризик господарська діяльність, що здійснюється суб'єктами господарювання (підприємцями) з метою досягнення економічних і соціальних результатів та одержання прибутку [4]. 
Економічні науки: збірник наукових прачь Луиького національного технічного університету. Серія "Регіональна економіка". Випуск 17 (67). Редкол.: відп. ред. к.е.н., професор І.В. Кривов'язюк. Луиьк: ІВВ Луцького НТУ, 2020. 348 с.

Водночас аграрне підприємництво, на думку В. Іванюти, є сукупністю політичних, соціальних, економічних та екологічних відносин між суспільством і його членами, що виникають у процесі володіння, користування та розпоряджання землею на рівні суспільства, регіону, місцевої громади 3 приводу виробництва, розподілу, обміну та споживання аграрної продукції. У результаті виникає структура взаємовідносин, яка володіє власними врегульовуючими механізмами. Як наслідок 3'являється цілий аграрний сектор [5].

Широке обгрунтування поняття аграрного сектору подано I. Сурай. Науковець тлумачить його як сферу яка охоплює всі підприємства України, незалежно від форми власності й організаційно-правової форми, що виробляють сільськогосподарську продукцію та продукти іiі первинної переробки й пов'язані з ними обслуговуючі підприємства, а також організації (установи), що здійснюють розробку та реалізацію державної аграрної політики. Тобто це сектор економіки, що охоплює всі підприємства, які виробляють сільськогосподарську продукцію, здійснюють іiі первинну переробку та обслуговують зазначені процеси [11, с. 263]. Наведене тлумачення дає можливість окреслити інституційний підхід до організації діяльності суб'єктів аграрного господарювання, в тому числі й аграрного підприємництва.

Сфера аграрного підприємництва охоплює фермерство як одну з організаційно-правових приватних форм господарювання в сільській місцевості. Фермерське господарювання у правовому полі визначається як форма підприємництва громадян 3 метою виробництва, переробки та реалізації товарної сільськогосподарської продукції [9]. При цьому суб'єкт економічної діяльності, зайнятий фермерською діяльністю, передусім зосереджується на створенні матеріальних цінностей шляхом ведення власного господарства. Саме фермер отримує первинний продукт (сировину для переробних підприємств), яким він розпоряджається на свою користь. Зазначимо, що об'єктом діяльності фермера можуть бути різні галузі тваринництва чи рослинництва. 
Економічні науки: збірник наукових прачь Луиького національного технічного університету. Серія "Регіональна економіка". Випуск 17 (67). Редкол.: відп. ред. к.е.н., професор І.В. Кривов'язюк. Луиьк: ІВВ Луцького НТУ, 2020. 348 с.

У Законі України „Про фермерське господарство” [9] зазначено, що фермерське господарство може бути створено одним або кількома громадянами України, які є родичами або членами сім’ї. Відповідно до закону фермерське господарство може існувати в статусі фізичної чи юридичної особи. Але найголовніше те, що фермер $\epsilon$ власником землі сільськогосподарського призначення і особисто зацікавлений у збереженні іiі родючих властивостей та належному використанні, натомість має право вільно розпоряджатись земельною ділянкою, передавати ії в оренду, заставу, спадщину. 3 огляду на зазначене, є надія на те, що фермер-господар, володіючи землею, не допустить зниження ii родючості, дбайливо на ній господарюватиме тривалий період, що в цілому сприятиме розвитку сільських територій, розбудові інфраструктурного забезпечення тощо. Прив'язка фермера до землі $\epsilon$ тим правовим фундаментом, який при грамотній державній підтримці та регулюванні дасть можливість розвинути фермерську діяльність як у напрямі розвитку дрібного (до 5 га), малого (5-20 га), так і середнього (20-100 га) фермерства.

Одним 3 видів діяльності суб'єктів підприємництва $є$ аграрний бізнес (агробізнес), який зумовлюється багатофункціональністю через поєднання економічних інтересів i взаємовідносин між виробниками сільськогосподарської продукції, промисловістю й сферою торгівлі, де відбувається реалізація товарів.

Сутнісне розуміння агробізнесу через призму його функціональності у науковій літературі подається як:

- сукупність суб'єктів підприємницької діяльності, які діють в аграрному секторі економіки країни. Сюди входить підприємницька діяльність у виробництві засобів виробництва для сільського господарства; власне сільськогосподарське виробництво; зберігання, транспортування і переробка сільськогосподарської продукції та торгівля як сировиною, так i переробленою продукцією. До агробізнесу також входять усі види діяльності 3 обслуговування сільського господарства 
Економічні науки: збірник наукових прачь Луиького національного технічного університету. Серія "Регіональна економіка". Випуск 17 (67). Редкол.: відп. ред. к.е.н., професор І.В. Кривов'язюк. Луиьк: ІВВ Луцького НТУ, 2020. 348 с.

(агросервіс, ринкова інфраструктура). Крім цього, функціонально агробізнес - це новий тип економічних відносин між суб'єктами аграрного ринку, що характеризуються взаємовигідною співпрацею 3 урахуванням економічних інтересів усіх його учасників [1];

- економічні відносини між людьми 3 приводу організації власної справи, пов'язаної з використанням землі 3 метою отримання прибутку [3];

- форма підприємницької діяльності у сфері виробництва засобів виробництва для аграрного сектору, у сільськогосподарському виробництві, у сфері переробки і реалізації продукції, агросервісному обслуговуванні виробників. Водночас до аграрного бізнесу залучається все населення, коли розраховує витрати на продукти харчування [10].

Термін „агробізнес” як бізнес сільськогосподарського виробництва введено у науковий обіг у 1957 р. Джоном Девісом i Реєм Голдбергом [13]. Він включає підприємства сільськогосподарської хімії, селекції, виробництво продуктів рослинництва (землеробство або підрядне господарство), дистрибуцію, сільськогосподарську техніку, переробку та постачання насіння, а також маркетинг і роздрібний продаж. Сюди належать всі ланки ланцюга створення вартості харчових продуктів; установи, які впливають на нього, теж є частиною системи агробізнесу.

У контексті управління агробізнесом у наукових колах кожен окремий елемент виробництва та розподілу сільського господарства може бути охарактеризований як агропідприємство. Однак термін ,агробізнес” найчастіше підкреслює „взаємозалежність” цих галузей у межах „продуктового ланцюга”.

Узагальнення окремих підходів до понять, пов'язаних 3 аграрним підприємництвом, дає можливість стверджувати, що ï тлумачення має змістовне економічне підгрунтя. Господарювання в аграрній сфері пов'язано передусім із земельними відносинами, незалежно від форм власності, на його результативність впливає низка чинників, в основному 
Економічні науки: збірник наукових прачь Луиького національного технічного університету. Серія "Регіональна економіка". Випуск 17 (67). Редкол.: відп. ред. к.е.н., професор І.В. Кривов'язюк. Луиьк: ІВВ Луцького НТУ, 2020. 348 с.

природно-кліматичного, інвестиційно-інноваційного характеру. Вагомого значення при цьому набуває людський фактор, який поєднує як накопичений потенціал, так і людський капітал 3 його творчим началом і грамотністю та своєчасністю прийняття управлінських рішень з метою вирішення поточних проблем господарювання. Отже, аграрне підприємництво, на нашу думку, є специфічним видом економічної діяльності, у процесі якого задіюються значні ресурси, зокрема природно-кліматичні, інвестиційно-інноваційні, організаційно-фінансові, інтелектуальні тощо, які в сукупності у процесі виробництва сільськогосподарської продукції дають можливість підприємцю, незважаючи на ризик і високу відповідальність, на правовій основі отримувати прибуток. Водночас аграрне право повинно стосуватися тих правових відносин у процесі аграрного господарювання, які уможливлять дотримання балансу між максимізацією прибутку i раціональним, бережливим ставленням до природних ресурсів, використовуваних у процесі виробництва продукції сільського господарства.

\section{Список бібліографічного опису}

1. Абрамович I.A. Теоретичні основи та форми прояву аграрного бізнесу//Ефективна економіка. 2011. № 12. URL: nbuv.gov.ua > j-pdf > efek_2

2. Аграрне право України: підручник//за ред. В.М. Гайворонського, В.П. Жушмана. Х.: Право, 2003. 112 с.

3. Андрусенко Г.О., Мартьянов В.П. та ін. Організація агробізнесу і підприємництва: навч. посіб./за ред. В.П. Мартьянова; Харк. держ. аграр.ун-т ім. В.В.Докучаєва. Харків, 1998. 280 с.

4. Господарський кодекс України від 16 січня 2003 року № 436-IV (станом на 03.02.2013 р.) // Відомості Верховної Ради України. 2003. №18. №19-20, №21-22. Ст. 144. URL: https://zakon.rada.gov.ua/laws/show/43615\#Text

5. Іванюта В.Ф. Роль аграрного підприємництва в розвитку сільських територій у контексті євроінтеграції/Економічний вісник. 2016. №1. С. 61.

6. Конспект лекцій для бакалаврів усіх галузей знань денної форми навчання. Луцьк: Луцький НТУ, 2017. 111 с.

7. Курило В.І. Про зміст та співвідношення деяких аграрних дефініцій//Економіка АПК. 2014. № 2. С. 87-92.

8. Малік М.Й., Шпикуляк О.Г. Розвиток підприємництва в аграрному секторі економіки//Економіка АПК. 2006. № 4. С. 3-10.

9. Поняття суб'єктів аграрного права та їх класифікація. URL: http://yurist-online.com/ukr/uslugi/yuristam/literatura/agrar-pravo/39.php 
Економічні науки: збірник наукових прачь Луиького національного технічного університету. Серія "Регіональна економіка". Випуск 17 (67). Редкол.: відп. ред. к.е.н., професор І.В. Кривов’язюк. Луцьк: ІВВ Луцького НТУ, 2020. 348 с.

10. Про фермерське господарство: Закон України від 19.06.2003 № 973IV. URL: http://search.ligazakon.ua/1_doc2.nsf/link1/T030973.html

11. Семенов В.Ф., Сіваченко І.Ю., Федоряк В.П. Загальний курс агробізнесу: навч. посіб./за ред. В.Ф. Семенова, І.Ю. Сіваченка. К.: Т-во “Знання”. КОО, 2000. 301 с.

12. Сурай І.Г. Державне управління аграрним сектором економіки України: функціонально-структурний аспект :дис. ... канд. наук з держ. упр.: 25.00.02 Нац. акад. держ. упр. при Президентові України. Київ, 2005. 280 с.

13. Цимбалюк I., Риковська Л. Теоретичний аналіз сутності та складників дефініції «аграрна сфера»// Економічна теорія та історія економічної думки. № 4. 2017. С. 13-14.

14. Davis, John H.; Goldberg, Ray A. (1957). A Concept of Agribusiness. Division of Research, Graduate School of Business Administration, Harvard University.

\section{References}

1. Abramovych I. (2011) Teoretychni osnovy ta formy proiavu ahrarnoho biznesu [Theoretical bases and forms of agrarian businesses manifestation] Efektyvna ekonomika [Efficient economy], 12 [in Ukrainian].

URL. <nbuv.gov.ua > j-pdf > efek_2 >

2. Ahrarne pravo Ukrainy: pidruchnyk//za red. V.M. Haivoronskoho, V.P. Zhushmana [Agrarian law of Ukraine textbook // ed. V. Haivoronskyi, V. Zhushman] (2003) Pravo [Law], Kharkiv [in Ukrainian].

3. Andrusenko H., Martianov V. and other (1998) Orhanizatsiia ahrobiznesu i pidpryiemnytstva: navch. posib. [Organization of agrarian business and entrepreneurship: a textbook] Kharkivskyi natsionalnyi ahrarnyi universytet im. V. Dokuchaieva [V. Dokuchaev Kharkiv National Agrarian University], Kharkiv [in Ukrainian].

4. Hospodarskyi kodeks Ukrainy (vid 16.01.2003) [Commercial Code of Ukraine (from 16.01.2003)] Vidomosti Verkhovnoi Rady Ukrainy [Information of the Verkhovna Rada of Ukraine], 18-22. [in Ukrainian].

URL. < https://zakon.rada.gov.ua/laws/show/436-15\#Text >

5. Ivaniuta V. (2016) Rol ahrarnoho pidpryiemnytstva v rozvytku silskykh terytorii u konteksti yevrointehratsii [The agricultural entrepreneurship role of rural development in the context of European integration] Ekonomichnyi visnyk [Economic Bulletin], 1, 61 [in Ukrainian].

6. Konspekt lektsii dlia bakalavriv usikh haluzei znan dennoi formy navchannia [Lecture notes for bachelors of full-time knowledge] (2017) Lutskyi Natsionalnyi Tekhnichnyi Universytet [Lutsk National Technical University] [in Ukrainian].

7. Kurylo V. (2014) Pro zmist ta spivvidnoshennia deiakykh ahrarnykh definitsii [On the content and correlation of some agrarian definitions] Ekonomika $A P K$ [Ekonomika APK], 2, 87-92 [in Ukrainian]. 
Економічні науки: збірник наукових прачь Луиького національного технічного університету. Серія "Регіональна економіка". Випуск 17 (67). Редкол.: відп. ред. к.е.н., професор І.В. Кривов’язюк. Луцьк: ІВВ Луцького НТУ, 2020. 348 с.

8. Malik M., Shpykuliak O. (2006) Rozvytok pidpryiemnytstva v ahrarnomu sektori ekonomiky [Entrepreneurship development in the agricultural sector of the economy] Ekonomika APK [Ekonomika APK], 4, 3-10 [in Ukrainian].

9. Poniattia subiektiv ahrarnoho prava ta yikh klasyfikatsiia [The concept of agrarian law subjects and their classification]

URL. $\quad<\mathrm{http}: / /$ yurist-online.com/ukr/uslugi/yuristam/literatura/agrarpravo/39.php >

10. Pro fermerske hospodarstvo: Zakon Ukrainy (vid 19.06.2003) № 973-IV [On farming: Law of Ukraine (from 19.07.2003) № 973-IV] Vidomosti Verkhovnoi Rady Ukrainy [Information of the Verkhovna Rada of Ukraine], [in Ukrainian], 45.

URL. <http://search.ligazakon.ua/__doc2.nsf/link1/T030973.html >

11. Semenov V., Sivachenko I., Fedoriak V. (2000) Zahalnyi kurs ahrobiznesu: navch. posib. [General course of agribusiness: textbook] Znannia [The Knowledge], Kyiv [in Ukrainian].

12. Surai I. (2005) Derzhavne upravlinnia ahrarnym sektorom ekonomiky Ukrainy: funktsionalno-strukturnyi aspekt [Public administration of the agricultural sector of the economy of Ukraine: functional and structural aspect], Natsionalna akademiia nauk pry prezydentovi Ukrainy [National Academy of Sciences under the President of Ukraine], Kyiv [in Ukrainian].

13. Tsymbaliuk I., Rykovska L. (2017) Teoretychnyi analiz sutnosti ta skladnykiv definitsii «ahrarna sfera» [Theoretical analysis of the essence and components of the definition of «agricultural sphere»] Ekonomichna teoriia ta istoriia ekonomichnoi dumky [Economic theory and history of economic thought], 4, $13-14$.

14. Davis J., Goldberg R. (1957). A Concept of Agribusiness. Division of Research, Graduate School of Business Administration, Harvard University. 